\title{
EZIKOSLOVLJE
}

20.1 (2019): 119-146

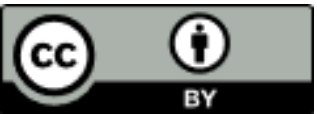

UDC 811.163.42'272=111

811.163.42'373.613:811.111=111

Original scientific article

Received on 30.08. 2018

Accepted for publication on 29.03. 2019

https://doi.org/10.29162/jez.2019.5

\section{Emilija Mustapić}

University of Zadar

\section{From šećerna tabla to čoCROlada: A study of multilingual discourse on Croatian food labels}

The study of linguistic landscape (LL) encompasses the language of public signs, commercial billboards, and other forms of written texts displayed in public (mostly urban) spaces of a particular geographical location. Its dual function, informational and symbolic, provides fertile ground for research into multilingualism, a phenomenon prevalent in today's society. LL is made up of both large-scale entities such as billboards, and smaller everyday items such as leaflets, posters, and food labels. The aim of this paper is to explore the multilingual discourse on Croatian food labels with a special focus on the advent of words and expressions from the English language. Our quantitative examination of chocolate labels from the 1960s until 2010, presented in the first part of the paper, suggests that the Croatian LL has indeed embraced English (and other languages to some extent) and shifted from primarily monolingual to multilingual practice. Our qualitative analysis of contemporary Croatian chocolate labels in terms of language content relationship and visual arrangement, presented in the second part, indicates a strong English influence on shaping the Croatian LL in the realm of food labelling. It, therefore, confirms the widely held idea that English has become a key component of product marketing.

Key words: linguistic landscape; Croatian food labels; multilingualism; English. 


\section{Emilija Mustapić: \\ From šećerna tabla to čoCROlada: A study of multilingual discourse on Croatian food labels}

\section{Introduction: linguistic landscape $(\mathbf{L L})^{1}$}

Material culture, with all its necessities, objects, and inventions, is an essential part of any society. Objects of material culture are usually interwoven with the linguistic environment, which makes their analysis crucial for a better understanding of the linguistic reality of a particular community. When material objects have writings in two or more languages, they can be identified as bilingual or multilingual. By reflecting both social and linguistic reality, these objects become a part of diverse culture and, consequently, have an important role in language reception and use (O'Laoire \& Aronin 2011: 1-4). Multilingualism is a very complex phenomenon, which has drawn much attention lately and has been approached from a variety of angles. One of the most prominent approaches to the study of multilingualism in material culture is the study of written information on language signs known as linguistic landscape (Cenoz \& Gorter 2006: 67). Offering valuable insight into the socio-cultural structure of the community, the study of LL has been in the limelight not only in modern linguistics but also in some other academic disciplines, such as psychology, anthropology, and cultural geography (Shohamy \& Waksman 2009). Since the function of LL in society is both informational and symbolic (Landry \& Bourhis 1997: 26), LL requires a thorough analysis from various perspectives.

The concept of linguistic landscape was first introduced by Canadian researchers Landry \& Bourhis (1997) in the context of language planning and ethnolinguistic vitality. Even though the idea of linguistic landscape dates back to the 1980s and to the language planners who first suggested forming the boundaries of linguistic territories ${ }^{2}$ and regulating the languages of public signs and names (Landry \& Bourhis 1997: 24), it was not until Landry and Bourhis conducted their empirical study that other linguists started examining the language of public signs (Edelman 2006). Linguistic landscape is classified as a sociolinguistic subdiscipline ${ }^{3}$ and is

\footnotetext{
${ }^{1}$ In the literature on linguistic landscape, the abbreviation LL is used ambiguously - as a term for both the subdiscipline and its object of study, for instance, LL studies, LL research, LL analysis (Barni \& Bagna 2015); exploration of the LL, LL data collection (Blackwood 2015); principles of LL, LL investigations (Ben-Rafael \& Ben-Rafael 2015). In this paper, the spelled-out form "linguistic landscape" will be used to refer to the linguistic subdiscipline, while the abbreviation "LL" will stand for the object of study.

${ }^{2}$ Establishing the boundaries in bilingual or multilingual territories could resolve language conflicts, as witnessed by Belgium in the 1980s when the country was divided into two self-administered monolingual territories; Flemish in the north and French in the south (Landry and Bourhis 1997: 24).

${ }^{3}$ Cenoz and Gorter focus on the bidirectional relationship between a sociolinguistic context and LL. On the one hand, LL "reflects the relative power and status of the different languages in a specific sociolinguistic context" (2006: 67), i.e. it is an additional source of information about a current so-
} 


\section{EZIKOSLOVLJE \\ 20.1 (2019): 119-146}

based on a few recently developed theoretical preliminaries (Backhaus 2007: 3). Since linguistic landscape is still a relatively new concept, the interpretations and definitions of its object of inquiry are quite diverse. Ben-Rafael et al. define LL as "any sign or announcement located outside or inside a public institution or a private business in a given geographical location" (2006: 14). Still, the most cited is Landry and Bourhis' pioneering definition of LL as:

"[T]he language of public road signs, advertising billboards, street names, place names, commercial shop signs, and public signs on government buildings combines to form the linguistic landscape of a given territory, region or urban agglomeration" (1997: 25).

A sign, the basic element of LL, is described as "[...] a notice on public display that gives information or instruction in a written or symbolic form" ${ }^{\text {" }}$ (Backhaus 2007: 4). There are two types of signs in LL - public and commercial signs. ${ }^{5}$ Public signs are used for general public interest ${ }^{6}$ such as providing directions, warnings, and geographical information, whereas commercial signs are typical of product advertising and marketing. Essentially the same classification of signs in LL was given by Calvet, who distinguishes in vitro and in vivo signs. In vitro signs are used by the government entities (traffic signs, toponymic signs, etc.); in vivo signs include diverse commercial markers from the private sector such as advertisements or shop front signs (Backhaus 2007: 32). According to Gorter's typology (2006), signs in LL perform nine different functions. They are (1) business names, (2) business signs, (3) graffiti, (4) information, (5) instructions, (6) product labels, (7) legends, such as slogans or trades association membership stickers, (8) street names, and (9) trademarks. All of these functions fit Landry and Bourhis'pioneering definition of the sign as any writing displayed in the public space. Considering a broad definition of the LL sign and its plausible classifications, Torkington (2009) argues that Landry and Bourhis' definition of LL does not encapsulate all the constituents of the public space that could be perceived as signs, but the following elements only (Landry \& Bourhis 1997: 26-27): (a) private signs such as commercial signs on

ciolinguistic situation. On the other hand, LL affects the linguistic choice of individuals, which creates a current sociolinguistic frame (2006: 68).

${ }^{4}$ Although it is rather questionable whether all signs are ideological or not, it is assumed that they all have the potential of becoming the symbolic indicators of social status and power (Kress 1993: 174 quoted by Torkington 2009: 123).

${ }^{5}$ Named also as "top-down" and "bottom-up" signs (Ben-Rafael et al. 2006); "official" and "nonofficial" signs (Backhaus 2007).

${ }^{6}$ Following Backhaus' thesis, there is no clear-cut distinction between public and commercial signs because they both give information of general interest (2007: 5). 


\section{Emilija Mustapić: \\ From šećerna tabla to čoCROlada: A study of multilingual discourse on Croatian food labels}

shops and banks, commercial billboards, advertisements displayed on private vehicles and public transportation; (b) government signs such as road signs, place and street names, signs on government buildings, etc. She claims that Landry and Bourhis considered only fixed signs as LL components - writings which are stable in space (such as road signs or billboards), without including other types of texts in the public space - mobile forms of texts such as leaflets, flyers on the streets, advertisements on buses and cars, tourist maps, and other written items available on public counters and desks (2009: 124). Torkington's criticism may be a bit strong since Landry and Bourhis did mention some types of mobile texts in their classification (advertisements on the vehicles), even if they did not single them out in their definition. Sebba's LL typology is consistent with the aforementioned classifications. He distinguishes between fixed and mobile public texts (such as product labels, stamps, banknotes, tickets, or handbills), but also puts emphasis on their similarities. It is argued that: (a) they both belong to the public sphere and are publicly noticeable; (b) their authority and authenticity are often presented similarly, and (c) both types of public texts can be delineated in several discourses and give additional information about the public subject (2010: 59-61). As can be concluded from these categorisations, most signs in LL are grouped according to their function (public or commercial) and moveability (fixed or mobile) in the public space.

Another parameter worth mentioning for the purpose of our analysis is the position of a sign in LL. Most fixed public signs are placed outdoors, but mobile commercial signs can be found in various locations. Ben-Rafael et al. maintain that any sign placed inside or outside a private business in a given geographical location is relevant for the study of LL (2006: 14). On the other hand, there are authors who limit their LL studies to the outdoor space only (see Edelman's (2006) analysis of the shopping streets in Amsterdam). This may leave the impression that the items of shop interiors, cinemas, or buses are not of interest to the study of LL; however, shops or cinemas are commercial places where people bond or exchange products and services and it is hard to escape the conclusion that the items found therein should also be analysed as part of LL. In general, we are inclined to believe that all these classifications should be considered when investigating the LL of a particular community in order to understand how each parameter reflects and modifies signs, as the essential components of LL.

In this paper, we will assume this broad orientation and analyse product labels, viz. mobile commercial LL signs, whose characteristics are still somewhat unexplored. Hopefully, in this way we will contribute to the growing body of research on LL, which involve objects in the public space as diverse as bilingual shop fronts (Kallen \& Ni Dhonnacha 2010), graffiti (Pennycook 2009), manhole covers (Tufi 
\& Blackwood 2010), alcoholic and non-alcoholic beverages (Blackwood, forthcoming), food produce such as milk (Sebba 2010) and honey (Blackwood \& Tufi 2012), printed T-shirts (Caldwell 2016, 2017), even human bodies as the media for tattoo artists (Peck \& Stroud 2015). One might even propose that - due to their transportability and ubiquity in the global consumerist society - mobile signs, such as food and drink labels, clothing, and tattoos, should be of central interest to the study of LL. The analysis of advertisements for chocolate wraps or food products in general, starts with the label. But being an essential part of the product itself, the label can appear anywhere. It represents the primary shape of the product, and comes to be featured on billboards, in TV advertisements, online catalogues, social networks, and other media. Therefore, food labels provide an important stepping stone for a more systematic and general LL study of food product signs in general. Ultimately, as mobile, small-sized, commercial signs located in the public sphere, food labels are no less deserving of a meticulous LL analysis than any other, largescale objects such as billboards, private commercial signs, bus advertisements, etc.

\section{Challenges in $L L$ research}

LL studies have undergone considerable change since the publication of Landry and Bourhis' (1997) groundbreaking study. New methodologies and approaches have emerged and have been deployed to provide more extensive and complex analyses of various features of LL. The common perception is that the study of LL is a contemporary trend, but Pavlenko and Mullen claim that "linguistic landscapes are by no means modern phenomena" (2015: 114). Studies have shown that the foundations of LL studies were laid down in antiquity. By analysing ancient inscriptions on monuments and other static and non-static objects in the public spaces, the classicists introduced the concept of "epigraphic landscapes" which, for many reasons, resembles today's idea of LL. Still, in spite of the obvious similarities between the epigraphic and contemporary LL, a methodological or theoretical unification between ancient and contemporary studies and approaches would be fraught with difficulties (due to e.g. non-unified terminology, different material availability, etc.). However, the benefits of combining ancient and modern research of LL should outweigh the drawbacks. This would enable a productive interdisciplinary "dialogue", since findings from the past can help clarify the postulates of contemporary LL. At the same time, modern principles of LL could help reexamine some ancient research traditions (Pavlenko \& Mullen 2015).

In the past twenty years, the methodologies developed for LL studies in the context of multilingualism have been mainly quantitative, and they have been used for 


\section{Emilija Mustapić: \\ From šećerna tabla to čoCROlada: A study of multilingual discourse on Croatian food labels}

gathering information and contextualising language use (investigating the coexistence of languages, the relations between dominant and minor languages, and the influence of English as a global language). ${ }^{7}$ However, LL research has also engendered some interdisciplinary approaches (such as semiotic, sociological, geographical, economic, political, etc.), which apply not only quantitative but also qualitative research methods such as interviews, observations, or note-taking as a part of fieldwork (Barni \& Bagna 2015). A combined quantitative-qualitative methodology to LL alleviated the shortcomings of using either methodology alone. While a quantitative analysis can be used to contextualise and compare the data across time and space, a qualitative analysis can provide crucial insights about the symbolic power of individual signs. According to Blackwood, this "marriage of two methodologies [...] is significant since the conclusions to which, in combination, they point are greater than the sum of their parts" (2015: 51).

Another interesting research perspective comes from Pavlenko and Mullen; they give precedence to diachronicity over synchronicity since "[...] the interpretation of signs is intrinsically linked to the preceding signs in the same environment and to related signs and is thus diachronic in nature" (2015: 114-115). These authors also believe that whatever approach to LL one intends to use, they are all bound to be subjective because
"[T]he moment we start looking back, we realize that in the study of contem- porary situations we bring a great deal of implicit knowledge to the task all the while believing we are 'reading back' in some systematic and objective way from the signs. In the study of the past, be it recent or remote, such knowledge cannot be taken for granted and, as with all historical disciplines, it is crucial to establish what plausible assumptions can be made when we actu- ally do 'read back' from signs to (discontinued) practices and (absent) people and what constraints should be placed on these assumptions" (Pavlenko \& Mullen 2015: 116).

While one might argue that subjectivity is seen as controversial, debatable, and undesirable in some domains of linguistic research, there seems to be considerable agreement among some LL researchers (e.g. Leeman \& Modan 2009; Pavlenko \& Mullen 2015; Malinowski 2015) that subjectivity in LL cannot be avoided. For one, there is still no consensus on what would be adequate, objective, and verifiable alternatives. Although the theoretical and methodological postulates of LL are still in the early stages of development, all research of LL should be replicable and

\footnotetext{
${ }^{7}$ For examples of quantitative analysis, cf. Ben-Rafael et al. (2006), Blackwood (2015), Barni \& Bagna (2015).
} 
with verifiable results. That often entails a rigorous research approach, and methodological refinements to deal with problems like, e.g., sign dynamism impeding data collection, difficulties in defining the units of analysis due to lack of normative criteria for observations, etc. (cf. Gorter \& Cenoz 2017 and the references cited therein). As will transpire soon, we will adopt a combined qualitative-quantitative approach. While we do not claim that this will guarantee a completely bias-free, objective interpretation of our data, we do believe that the approach is sound and can deliver reliable results and interpretations.

Since our analysis deals with the (diachronic) analysis of multilingual signs on consumer products, in the next section we present a short overview of multilingualism in marketing, and then move on to present details of the present study.

\section{Multilingualism in product marketing}

The global market and consumerism have made the economic identity of contemporary society more dominant than its political identities, which resulted in a shift from monolingual to multilingual social practices. Complex cultural identities have been moulded under the influence of the media, internationally-oriented advertising, and capitalism. Outgrowing national borders, globalisation has become a crucial creator of not only political and economic, but also linguistic identities. The monolingual identities of $18^{\text {th }}$ and $19^{\text {th }}$ Europe have given way to European linguistic identities that are multilingual and involve predominantly English. By combining native and foreign languages, multilingual discourse has become the greatest novelty in contemporary advertising, and it will continue to expand in future. This phenomenon is typical of modern LL (Piller 2001) and it is hardly surprising that there is a growing number of studies examining the influence of multilingual discourse on prospective consumers and product advertising (Piller 2003: 170-171).

Piller argues that the consumption of products and services is the key element that shapes consumers' preferences in capitalist society (2001: 156), which is why the influence of multilingual discourse on product advertising and design seems unquestionable. LL signs such as street names, billboards, and shop names clearly reflect the dynamics of multilingualism (cf. Griffin 2004; Backhaus 2005, 2007; Edelman 2006; Cenoz \& Gorter 2006; Bruyèl-Olmedo \& Juan-Garau 2009; Torkington 2009; Ben-Rafael \& Ben-Rafael 2015), but other public texts such as leaflets, product labels, or flyers should also come under scrutiny as conveyors of multilingual discourse. While the analyses of multilingual texts in newspaper advertisements, billboards, or posters have been quite numerous, which to some ex- 


\section{Emilija Mustapić: \\ From šećerna tabla to čoCROlada: A study of multilingual discourse on Croatian food labels}

tent is not surprising since they are commonly perceived as the most representative and popular commercial signs, other types of texts such as websites or product labels are still quite under-examined (Sebba 2012). Product labels on the packages are highly influential marketing factors, as they may directly affect the consumer's willingness to purchase the item. Considering that they are aesthetic, experiential, functional, symbolic, and informational communicators of the produce itself, it is surprising that, for all their merits, product labels remain quite an unexplored research topic when compared to other means of marketing (Underwood \& Ozanne 1998). Commercial signs like product labels have a non-specified population as their target, but they appear in the public space and contain visual features which may affect the semiotic structure of the information about the product or service (Piller 2001; Stroud \& Mpendukana 2010; Sebba 2012), and eventually lead to new sociolinguistic circumstances. The significance of product labels in LL has indeed been overlooked from the sociolinguistic perspective, which may seem odd if we consider that features of product labels like colour, shape, wording, and graphic style could play an important role in consumers' perception of the product (Run \& Fah 2006: 136). A detailed analysis of product labels should, therefore, follow a multimodal approach, and consider not only their linguistic properties, but also visual and spatial relationships of languages (Sebba 2012). We shall return to these issues in the analysis presented in Section 5.

Haarmann (paraphrased in Piller 2003: 172) states that the use of foreign language in advertising is seen as "[...] an attempt to associate the advertised product with an ethno-cultural stereotype about the speaker of a given language". It is not important whether the target group would understand the foreign content on the product, what matters is the product's identification with a particular language and culture. The use of a foreign language, especially the one which functions as a lingua franca, enables efficient multinational exchange of products. At the same time, employing English as a contemporary lingua franca "[...] leads to a growing familiarity with the English language, which positively affects the spread and the integration of English words into the receiver language" (Fischer 2008: 1). ${ }^{8}$ English is indeed the most frequent language found in LL of non-English speaking European

\footnotetext{
${ }^{8}$ It is important to add that the use of English in advertisements is twofold - it can be used as a language of international communication, with no symbolic reference to any nation or country in which it is an official language, or as the language of the specific countries in which it is spoken as the mother tongue (primarily in the USA and the UK) invoking the associated cultural values. While the latter is the case far less frequently, there are some cases in multilingual advertising where the English linguistic elements symbolise British or American values (e.g. stars and stripes, blue jeans, or Marlboro cigarettes denoting the American lifestyle) (Piller 2001: 164).
} 
countries (Edelman 2006), and is the authoritative component of multilingual discourse. In his examination of Japanese ethno-cultural stereotyping on multilingual products, Haarmann found that the English-oriented positive stereotypes included qualities such as "international appreciation, reliability, high quality, confidence, practical use and practical lifestyle". English was found to be used for the promotion of products such as cars, alcohol, TV gadgets, and sports equipment, but its function was argued to be purely symbolic because Japanese readers generally could not understand the English words and phrases (Piller 2003: 172). Many nonEnglish food companies use English on their product labels because "Everyone wants to be perceived as a global player, and such a perception is best achieved through the use of English" (Piller 2001: 161). Add to that the common perception that products are predominantly more valuable if they possess English attributes. ${ }^{9}$

Needless to say, globalisation and consumerism have also made a strong impact on product marketing in Croatia. Multilingualism has become a major research topic not only among marketing experts, but also among Croatian linguists (Mihaljević 1993, 2006; Drljača 2006; Stolac \& Vlastelić 2014). Croatian advertising has no doubt changed under the influence of these trends and the search for new and innovative communication channels between the producer and the consumer has led to new approaches to product marketing. Language has always been a key instrument in product advertising, but it also plays a vital role in enabling companies to find creative ways to adapt to the new consumer profile (GjuranCoha \& Pavlović 2009).

Travelling through high-traffic urban centres in Croatia or along Croatian highways, one can notice a number of visually appealing billboards advertising Croatian products with slogans written in English, German, Italian, or Czech. While the advertisers might justify this by claiming they wanted to attract tourists as their new target group of consumers, Stolac \& Vlastelić (2014) are sceptical about the extent to which the multilingual marketing technique is influenced by tourism, especially when advertisements designed for the domestic market are also taken into account. Such advertisements are often saturated with English linguistic elements, which may even outnumber the elements from Croatian. Stolac and Vlastelić attribute this trend primarily to the desire to evoke a particular image associated with the use of English and see this as a reflection of globalisation and asymmetrical power relations between "big" and "small" languages. They claim that English is becoming the language of prestige in economy and politics, and that its use in ad-

\footnotetext{
${ }^{9}$ Haarmann (1989) described the prestige functions of foreign languages in Japanese society.
} 


\section{Emilija Mustapić: \\ From šećerna tabla to čoCROlada: A study of multilingual discourse on Croatian food labels}

vertising is primarily a fad. ${ }^{10}$ In their research, the authors report several changes in the Croatian advertising domain, among them, the interplay of English and Croatian, the use of non-native linguistic elements in product names and descriptions (primarily English, but also German, French, Italian, and Brazilian Portuguese during the 2014 World Cup). However, a minor downside is that their study is based on advertisements created for/by both foreign and domestic companies. We believe a targeted examination of advertising by Croatian companies only would yield a better insight into the questions examined in this paper.

Let us conclude this section with a few notes on purism. Purism has always been an important element of Croatian language policy, and it seems deeply embedded in the cultural and national identity of its speakers (Katičić 1992; Babić 2004; Opačić 2007). And yet, despite all purist tendencies, Croatian (like many other European languages) has seen a steady influx of English words. An important trigger is, of course, the constant development of modern technologies and communication channels; the consequence is a fairly easy infiltration of English words and practices into the Croatian language, culture, and society at large. Since a vast majority of recently coined words do originate from English speaking countries, which shape the global economy and the IT sector in particular, the tendency to adapt and adopt English words and expressions has become most evident in computer terminology (Mihaljević 1993; 2006), economy (Drljača 2006), and product marketing (Stolac \& Vlastelić 2014). Embracing the idea of internationalisation and the need for business expansion into the global market, Croatian food companies are dealing with new challenging trends which, among other requirements, imply reshaping the policy of product labelling and symbolism. Our analysis of the visual and linguistic features of Croatian food labels, to be presented shortly, was intended to provide insight into this new situation and, to some extent, indicate how Croatian food product labels have come to have the features that they do.

The aim of this study is to examine the Croatian LL by describing crucial properties of food labels, i.e. mobile texts which contribute to the shaping of consumers' purchase preferences. Specifically, taking into consideration the contemporary trend of multilingual advertising practices examined above, this study aims to provide answers to two main research questions:

(1) When did the inflow of foreign language elements (English in particular) into Croatian food, or specifically, chocolate labels become the strongest?

\footnotetext{
${ }^{10}$ We shall focus on the effects of English in the following section.
} 
(2) How are contemporary chocolate labels structured linguistically and paralinguistically?

\section{Methodology}

Examining all food labels would be too big a task for a study of this scope. We limited this study to the examination of labels of one product type, i.e. chocolate. Our corpus consists of chocolate labels developed by three major Croatian food companies; Kandit, Kraš, and Zvečevo. We consider only those products that are placed on the domestic, Croatian market. Our data has been obtained, with permission, from two different sources: the official websites of the Croatian food companies and from a collection of pictures taken with a digital camera at randomly chosen local supermarkets in the city of Zadar over the past two years. A total of 289 different product wraps were considered: 226 for a quantitative diachronic analysis and 63 for a qualitative synchronic analysis. Only the front side of the product was analysed because the back side usually contains nutritional information and commercially irrelevant health claims prescribed by the national food agency.

The first part of our study was designed to address our first research question. We carried out a quantitative analysis to find out how many Croatian chocolate labels contained English elements throughout history (from 1960s to 2010) ${ }^{11}$ and to determine when the influx of English elements on Croatian chocolate labels became the most widespread. In the second part of the study (designed to address our second research question), the products were first separated into two categories; monolingual (Croatian) and multilingual (Croatian, English, and other languages). A qualitative comparison of multilingual chocolate wraps (with a special focus on the Croatian and English elements) in terms of product name and product description was made according to the following parameters:

(1) language content relationship (Sebba 2012: 19): whether the labels featured equivalent texts (the same content in two or more languages), disjoint texts (different content in two or more languages), or overlapping texts (a mixed type, a part of the text is repeated, the rest is not);

(2) paralinguistic features such as colour layout and font size.

\footnotetext{
${ }^{11}$ Chocolate labels from earlier periods were unavailable.
} 


\section{Analysis and discussion}

As announced above, our study addressed two research questions. In Section 5.1 we present the results of our diachronic analysis of Croatian chocolate wraps. The goal of this analysis was to provide insight into the development of the bilingual Croatian-English labelling practice on Croatian chocolate wraps in the second half of the $20^{\text {th }}$ century. We were particularly interested in the apparently growing presence of the English linguistic element. We first present basic quantitative data on the relative proportion of the two languages on Croatian chocolate labels throughout the examined period. This is followed by a detailed qualitative analysis of the typical labels from each period. In Section 5.2, we present the results of our qualitative analysis of contemporary Croatian chocolate labelling practices, focusing on the linguistic and paralinguistic aspects of Croatian and English elements.

\subsection{A retrospect of Croatian chocolate labelling practices}

The main goal of the diachronic analysis was to establish whether any changes occurred in the proportion of labels that contained only Croatian in contrast to those that (also) contained English elements. As explained in Section 4, we performed a visual inspection of chocolate labels on the websites of the three biggest Croatian chocolate manufacturers. The analysed labels were assigned to three categories depending on their language profile: Croatian-only, English-only, or Croatian and English combined (cf. Table 1). Somewhat surprisingly, several instances of English-only chocolate labels were found. Although one could argue that these were products intended for foreign markets, due to the lack of pertinent information from the manufacturers we were unable to exclude the possibility that some of them were designed for the domestic market. The changes in the proportions for each type of label in the total number of chocolate wraps examined in these periods are visible from the observed and expected frequencies presented in Table 1.

The chi-squared test indicates that the difference between the analysed periods is statistically significant $\left(\chi^{2}=43.680, \mathrm{df}=8, \mathrm{p}<0.001\right) .{ }^{12}$ Cramer's V statistic of 0.31 also shows a strong association between the period and languages on the chocolate

\footnotetext{
12 Although some cells features expected frequency values below 5, we carried out the chi-squared test. Namely, Campbell (2007) claims that the minimum expected frequency of cells in a chisquared test was set at 5 somewhat arbitrarily and argues that the problems of the chi-squared test in cases where expected frequencies are below 5 can be avoided by applying the so-called ' $\mathrm{N}-1$ ' chisquared test, provided that the expected frequencies are 1 and above. For detail, see Campbell (2007) and Busing et al. (2016).
} 


\section{EZIKOSLOVLJE \\ 20.1 (2019): 119-146}

labels. By comparing the observed $(\mathrm{O})$ and expected $(\mathrm{E})$ values for these periods in Table 1, we can see that the Croatian-only labels are overrepresented in the first three observed periods (1960s, 1970s, and 1980s), slightly underrepresented during the 1990s and strongly underrepresented during the 2000s. The situation for the bilingual (Croatian-English) labels is inverse - they are underrepresented in the first three observed periods, slightly overrepresented during the 1990s and strongly overrepresented in the last period when the observed values for Croatian-English labels are almost two times higher than the expected values, while the observed values for Croatian-only labels are almost three times lower than the expected ones. Figure 1 illustrates this shift from predominantly Croatian-only labels in the 1960s and the 1970s to predominantly bilingual (Croatian-English) labels in the 2000s. Based on this, it can be argued that the 1990s represent the turning point in the analysis, as this is the last period during which the Croatian-only chocolate labels are the majority (and a very slight majority) and the first period in which the observed frequency of Croatian-only labels is lower than the expected frequency.

As can be seen from Figure 1, Croatian chocolate labels were predominantly monolingual between 1960s and 1980s.

Table 1. Observed $(\mathrm{O})$ and expected $(\mathrm{E})$ frequencies and row proportions of languages on Croatian chocolate labels

Croatian

Both

English

\begin{tabular}{lllllllll} 
& & Freq. & $\%$ & Freq. & $\%$ & Freq. & $\%$ & Total \\
\hline $1960 \mathrm{~s}$ & O & 21 & 70.00 & 8 & 26.67 & 1 & 3.33 & 30 \\
& E & $(17.26)$ & $(57.52)$ & $(10.88)$ & $(36.28)$ & $(1.86)$ & $(6.19)$ & \\
\hline $1970 \mathrm{~s}$ & O & 41 & 82.00 & 7 & 14.00 & 2 & 4.00 & 50 \\
& E & $(28.76)$ & $(57.52)$ & $(18.14)$ & $(36.28)$ & $(3.10)$ & $(6.19)$ & \\
\hline $1980 \mathrm{~s}$ & O & 33 & 63.46 & 15 & 28.85 & 4 & 7.69 & 52 \\
& E & $(29.91)$ & $(57.52)$ & $(18.87)$ & $(36.28)$ & $(3.22)$ & $(6.19)$ & \\
\hline $1990 \mathrm{~s}$ & O & 26 & 54.17 & 19 & 39.58 & 3 & 6.25 & 48 \\
& E & $(27.61)$ & $(57.52)$ & $(17.42)$ & $(36.28)$ & $(2.97)$ & $(6.19)$ & \\
\hline $2000 \mathrm{~s}$ & O & 9 & 19.57 & 33 & 71.74 & 4 & 8.70 & 46 \\
& E & $(26.46)$ & $(57.52)$ & $(16.69)$ & $(36.28)$ & $(2.85)$ & $(6.19)$ & \\
\hline Total & & 130 & & 82 & & 14 & & 226
\end{tabular}




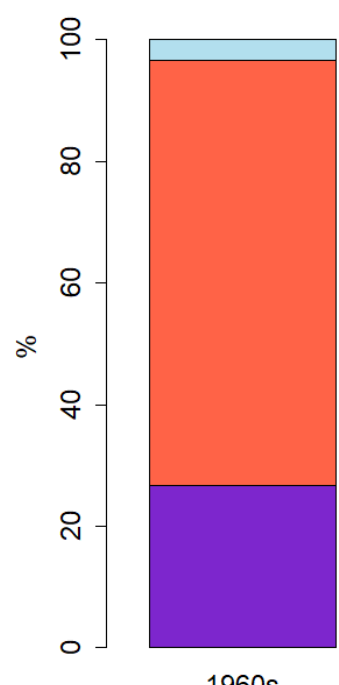

1960s

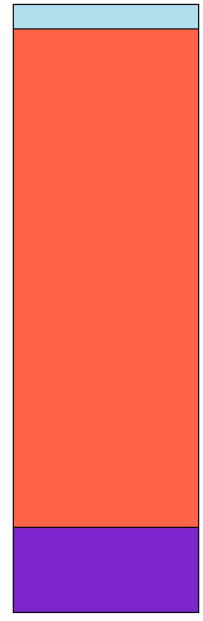

1970s

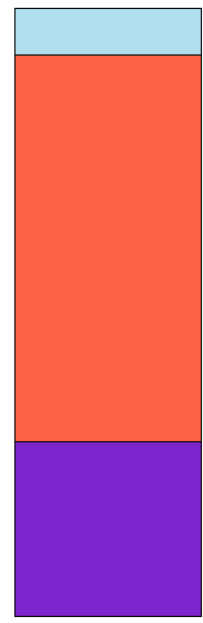

1980s

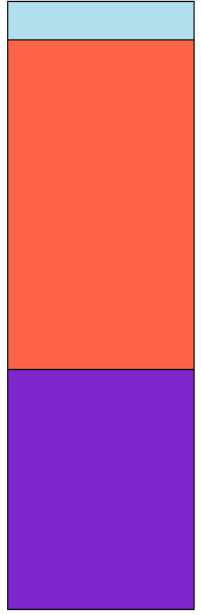

1990s

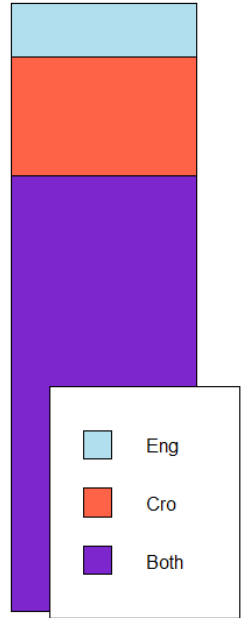

2000 s

Figure 1. Proportions of languages used on Croatian chocolate labels

Figure 2 illustrates labels typical of this period. The bold font and colour contrasts mark off the description of the product from its name and the content of each label is stated clearly and succinctly. For instance, Biljni svijet (lit. 'plant world'), Pinokio ('Pinnochio'), Badem ('almond'), Runolist ('edelweiss'). The layout often included visual motifs such as football players, actors, cartoon character, product ingredients, etc.

During the 1970 s, more than $80 \%$ of all chocolate labels were designed in Croatian, and the presence of English words was the lowest. Croatian was generally used as the sole language in product labelling (e.g. Super grožđice 'super raisins', Samo $t i$ 'only you', Dijetetska čokolada 'diet chocolate', Krokant čokolada 'croquant chocolate', Za Vas 'for you'), while foreign language elements (from English in particular $)^{13}$, however infrequent, were employed mainly in combination with Croatian in product names (e.g. Baby čokolada 'Baby chocolate', ZvečevoScope, Kraš Cinema mliječna čokolada 'Kraš cinema milk chocolate') to emphasise a particular ingredient (e.g. Coctail cognac s jajem 'cocktail cognac with egg', Cherry Kandit punjena čokolada 'cherry Kandit filled chocolate', Sandwich čoko-

\footnotetext{
${ }^{13}$ In the 1960s and the 1970s, several chocolate labels featured French elements: Kava crème, Čokolada de menage, Zvečevo chocolat au lait. In the 1980s, Italian was also in evidence; Victoria Cioccolato al latte con nocciole, made by Kandit food factory, presumably for the Italian market.
} 
lada 'sandwich chocolate', Butter-Scotch mliječna krem čokolada 'butter-scotch milk cream chocolate'), or in the form of orthographically adapted borrowings (e.g. Kandi ekstra 'Kandi extra'). English elements were also used when the chocolate contained a brand name (e.g. Cockta punjena čokolada 'Cockta filled chocolate'), or famous cartoon characters (e.g. Tom i Jerry šećerna tabla 'Tom and Jerry sugar bar', but also Prof. Baltazar šećerna ploča 'Prof. Baltazar sugar bar'). Until the 1980 s, less than $5 \%$ of labels were English-only (Figure 3).
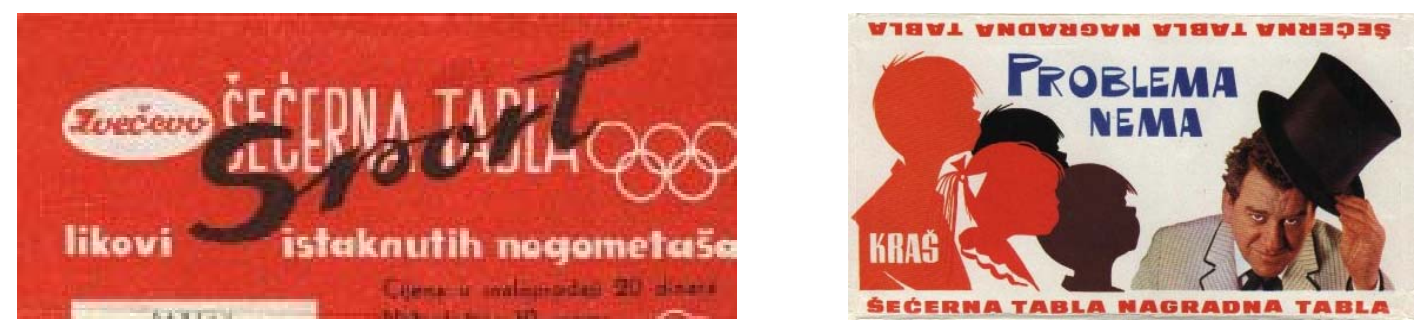

Figure 2. Croatian chocolate labels from the 1960s and the 1970s (URL1, URL 2) ${ }^{14}$

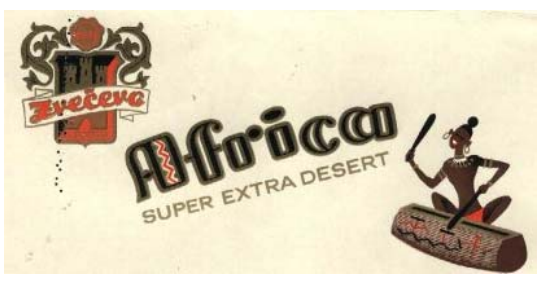

Figure 3. English label (1960s) (URL1) $)^{15}$

It was not uncommon to have the same type of chocolate from the same period in monolingual and bilingual form, each produced by a different food company (Figures 4 and 5).

As mentioned earlier, the 1990s represent the turning point at which the prevalence of Croatian started to decline. Although more than $50 \%$ of all chocolate labels in this period were still Croatian-only, an increase in the number of labels with the English element(s) announced new trends in product labelling.

\footnotetext{
${ }^{14} \mathrm{URL} 1 \mathrm{http}: / /$ www.chocolatewrappers.info/Vevropa/Zvecevo/zvecevo3.htm (last accessed on 1 June 2018); URL $2 \mathrm{http} / / / \mathrm{www} . \mathrm{kras} . \mathrm{hr} / \mathrm{hr} /$ proizvodi/cokolade/dorina (last accessed on 25 June 2018).

${ }^{15}$ URL 2 http://www.kras.hr/hr/proizvodi/cokolade/dorina (last accessed on 25 June 2018).
} 


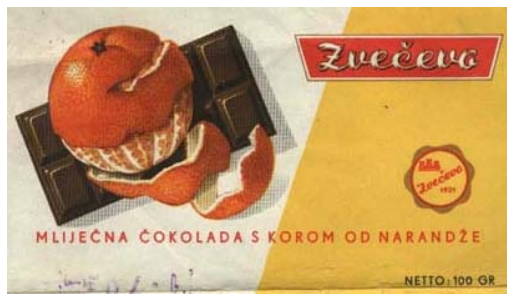

Figure 4. Monolingual label (1960s) (URL 2) ${ }^{16}$ 2) 17

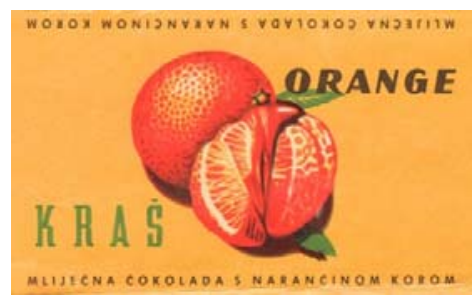

Figure 5. Bilingual label (1960s) (URL

Most products from the earlier periods were visually upgraded with no significant linguistic changes (such as Braco i Seka brother and sister', Runolist, Samo ti), but English became used increasingly more for naming new chocolate products (e.g. Croatia mliječna čokolada 'Croatia milk chocolate', Cro Army mliječna čokolada 'Cro Army milk chocolate', Lilly mliječna čokolada 'Lilly milk chocolate', All you need is love milk chocolate). Some labels feature English elements adapted orthographically to the Croatian spelling conventions (Figure 6).

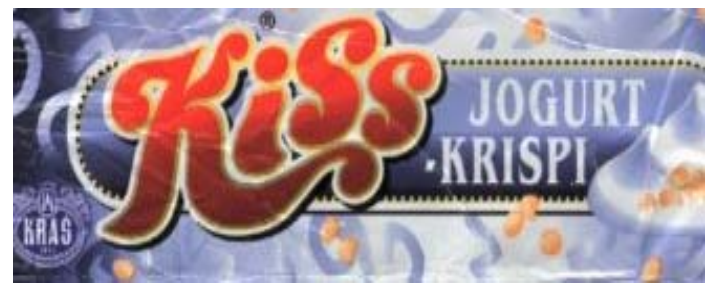

Figure 6. Orthographic adaptation of a label (URL 2) ${ }^{18}$ chocolate (URL 2) ${ }^{19}$

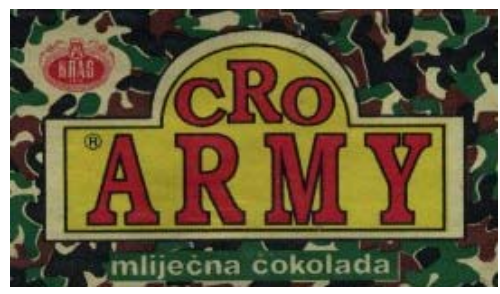

Figure 7. Wartime Croatian

The 2000s represent the final stage in the shift from predominantly monolingual Croatian labels to predominantly bilingual Croatian-English labels as more than $70 \%$ of labels in this period contained English elements, and less than $20 \%$ were Croatian-only. In comparison to the previous decade, when the use of English elements may have had a more symbolic meaning, reflecting the desire of newly independent Croatia to align itself with the western world (after the break-up with Yugoslavia), the expansion of English expressions on the Croatian chocolate labels at the beginning of the $21^{\text {st }}$ century may have been more economically-driven (e.g. Kandy Boy, Horror banana, Christmas Flight, Crispy, Full Cool, Fifty). By that

\footnotetext{
${ }^{16}$ URL 2 http://www.kras.hr/hr/proizvodi/cokolade/dorina (last accessed on 25 June 2018).

${ }^{17}$ URL 2 http://www.kras.hr/hr/proizvodi/cokolade/dorina (last accessed on 25 June 2018).

${ }^{18} \mathrm{URL} 2 \mathrm{http} / / / \mathrm{www} . \mathrm{kras} \cdot \mathrm{hr} / \mathrm{hr} / \mathrm{proizvodi} /$ cokolade/dorina (last accessed on 25 June 2018).

${ }^{19}$ URL 2 http://www.kras.hr/hr/proizvodi/cokolade/dorina (last accessed on 25 June 2018).
} 
point, the national food companies had embraced the changes in product marketing and shifted away from the monolingual, national profile of their products towards a multilingual and global one. Even though bilingual and multilingual labelling did occur even as far back as the 1960s and has continued to the present day (cf. Table 1), the presence of bi- and multilingual labels has never been as strong as in the last two decades.

The data presented in this section confirm the assumptions outlined in Section 3 regarding the effects of the global economy on Croatian chocolate labelling strategies. The shift from the predominantly monolingual Croatian-only labels of the 1960s to the mainly bilingual contemporary labelling practice is evidence of a strong trend towards internationalisation. However, lack of systematic research on why English elements on the Croatian food labels became so common and ubiquitous (especially considering their occurrence on other Croatian items which have not been included in this study such as, for example, the Croatian beverages or detergents) prevents us from finding a single cause of this phenomenon. In fact, the changes in the linguistic make-up of Croatian food labels could plausibly be attributed to a variety of factors that include at least: (a) globalisation and new trends in advertising and market expansion (Gjuran-Coha \& Pavlović 2009); (b) the perception of English as a language of prestige and quality (Haarman 1989; Piller 2003; Stolac \& Vlastelić 2014); (c) the creation of a new, internationally-oriented identity following the Croatian War of Independence; and (d) the creation of a tourist-friendly environment in the predominantly tourism-oriented Croatian economy. ${ }^{20}$ Although all these factors obviously play some role in the development of multilingual discourse on Croatian food labels and beyond, a comprehensive analysis of the impact of each of these factors and their interplay would require collaboration from a multidisciplinary team of experts, including historians, economists, linguists, and sociologists (cf. Barni \& Bagna 2015). This, unfortunately, lies beyond the scope of this paper.

\subsection{Contemporary labels}

In this part of the paper, we address our second research question by analysing the three main visual facets of contemporary chocolate labels - the product names, the product descriptions, and the paralinguistic features of the labels studied. In our qualitative analysis of product names and descriptions, we will comment on how particular linguistic choices were selected to project a particular desirable image. In

${ }^{20}$ The author would like to thank the anonymous reviewers for raising point (c). 
Emilija Mustapić:

From šećerna tabla to čoCROlada: A study of multilingual discourse on Croatian food labels

our analysis of the paralinguistic features we will focus on strategies used to highlight the multilingual quality of chocolate labels.

\subsubsection{Product name}

As shown above, we identified two general types of labels - monolingual labels, containing only Croatian or only English linguistic elements, and bilingual labels, containing linguistic elements from both languages. Here, we analyse product names (Section 5.2.1.) and product description (Section 5.2.2.) in terms of what Sebba (2012) calls "content relationship" - different ways in which elements of two (or possibly more) languages are interrelated.

Monolingual chocolate names clearly have no content relationship because the information is provided in a single language. As shown in Table 2, the presence of monolingual chocolate labels with English linguistic elements suggests that Croatian food companies started integrating English elements into the Croatian LL at least from the earliest period examined in this study, i.e. 1960s (cf. Section 5.1). Even though the majority of English product names could be substituted by a suitable Croatian equivalent, prestige and profit seem to be driving the use of foreign language elements on Croatian food labels. Therefore, it should come as no surprise to see the same type of chocolate with matching English-only and Croatianonly names sitting next to each other on store shelves, e.g. Happy Easter by Mikado and Mikado Sretan Uskrs!, or Dorina Mliječna and Dorina Milk. In some cases, it even seems that the English label may have been the advertiser's first choice since the Croatian counterpart would not even sound stylistically acceptable. For instance, if translated literally, the name of the Croatian chocolate Banana Buttons would sound crude and not too appealing for potential customers.

Table 2. Monolingualism in chocolate naming

\begin{tabular}{|l|l|}
\hline \multicolumn{1}{|c|}{$\begin{array}{c}\text { Monolingual } \\
\text { Croatian chocolate names }\end{array}$} & \multicolumn{1}{c|}{$\begin{array}{c}\text { Monolingual } \\
\text { English chocolate names }\end{array}$} \\
\hline Riki P̌̌enica i med & Mikado Premium Chocolate, \\
Dorina za jelo i kuhanje & Mikado Exclusive Chocolate, Mikado Classic \\
Dorina Mliječna & Kandi Chocodream Milk / Honey Crunch / \\
Mikado Mliječna čokolada & White Strawberry \\
Seka original & Prestige Kandi Whole Nuts / Crunchy Nuts \\
Braco original & /Almonds with Crunchy Caramel \\
& Dorina Cocoa Puffs / Fifty / Punch / Banana \\
& Buttons \\
\hline
\end{tabular}




\section{EZIKOSLOVLJE}

20.1 (2019): 119-146

Bilingual chocolate names are usually disjoint because two or more parts of the name are written in different languages and refer to something specific (Sebba 2012). The brand name is usually presented in English, while the ingredients tend to be rendered in Croatian (e.g. Kandi Chocodream Lješnjak sjeckani Kandi chocodream chopped hazelnut', Kandi Chocodream Kokos \& riža 'Kandi chocodream coconut \& rice', Kids Žitarice \& mlijeko 'Kids cereal \& milk'). These labels are prime examples of what Reh (2004) and Pavlenko \& Mullen (2015) regard as "overlapping" multilingualism - instances where a single message is conveyed by two mutually intertwined languages. An interesting example of this overlapping bilingual word play is the chocolate label created before the start of the 2018 FIFA World Cup in Russia. As shown in Figure 8, this label was designed to bring national identity into focus. The elements of the Croatian coat of arms and the English abbreviation for Croatia (CRO) are combined with the Croatian word cokolada 'chocolate' into the blend čoCROlada. This product capitalises on the 2018 football frenzy and by appealing to the sense of national pride it was meant to reach a wide consumer base - the Croatian football fan.

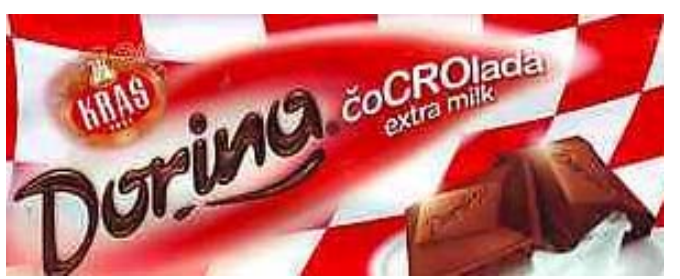

Figure 8. Footballmania on chocolate labels (URL 2) ${ }^{21}$

Bitter čokolada 'Bitter chocolate' is a perfect example of how resorting to English can help create a more positive product image than would be possible by using Croatian alone. For instance, the Croatian chocolate name Bitter čokolada consists of two parts - the English adjective bitter (gorak, gorka in Croatian) and the Croatian noun cokolada. Considering that the vast majority of contemporary products have monolingual names, Bitter čokolada proves to be one of the few exceptions because it combines two languages. We speculate that the company opted for the English word bitter in part at least to avoid the negative overtone of the Croatian translation equivalent gorak. The adjective gorak indicates an unpleasant flavour and unappealing taste. The English equivalent bitter euphemises the negative connotation and does not sound as unpleasant as the Croatian word, which is why it could affect the consumer's willingness to purchase a product. Beyond that, this strategy is certainly also driven by positive English-oriented stereotypes in interna-

${ }^{21}$ URL 2 http://www.kras.hr/hr/proizvodi/cokolade/dorina (last accessed on 25 June 2018). 


\section{Emilija Mustapić: \\ From šećerna tabla to čoCROlada: A study of multilingual discourse on Croatian food labels}

tional trade and advertising, i.e. the English linguistic elements being perceived as emblems of the quality and reliability of the products they describe (cf. Haarmann 1989; Piller 2003).

\subsubsection{Product description}

We found only a few examples of monolingual Croatian-only product descriptions (e.g. Poslužiti ohlađeno 'serve cold', Mliječna kakaova ploča s lješnjak punjenjem $i$ rižom 'milk cocoa bar with hazelnut filling and rice', Lješnjak + badem + grožđice 'hazelnut + almond + raisins', Kikiriki i karamela 'peanuts and caramel', Riža + mlijeko + žitarice 'rice + milk + cereal'), and several monolingual Englishonly product descriptions (e.g. Limited edition, Milk and dark chocolate with whole biscuits). There were many more bilingual, or trilingual product descriptions with the same content provided in two or three languages (Table 3): ${ }^{22}$

Table 3. Bilingual and trilingual product descriptions

\begin{tabular}{|c|c|c|c|c|}
\hline \multicolumn{2}{|c|}{ Bilingual product descriptions } & \multicolumn{3}{|c|}{ Trilingual product descriptions } \\
\hline $\begin{array}{l}\text { Čokolada s inte- } \\
\text { gralnom rižom }\end{array}$ & $\begin{array}{l}\text { Chocolate with } \\
\text { wholegrain rice }\end{array}$ & $\begin{array}{l}\text { Mliječna čoko- } \\
\text { lada s keksom }\end{array}$ & $\begin{array}{l}\text { Milk chocolate } \\
\text { with biscuit }\end{array}$ & $\begin{array}{l}\text { Chocolat au lait au } \\
\text { biscuit }\end{array}$ \\
\hline $\begin{array}{l}\text { Mliječna čokolada } \\
\text { s punjenjem }\end{array}$ & $\begin{array}{l}\text { Milk chocolate } \\
\text { with filling }\end{array}$ & $\begin{array}{l}\text { Mliječna čoko- } \\
\text { lada + vafel }\end{array}$ & $\begin{array}{l}\text { Milk chocolate } \\
+ \text { Wafer }\end{array}$ & $\begin{array}{l}\text { Chocolat au lait }+ \\
\text { Gaufrette }\end{array}$ \\
\hline $\begin{array}{l}\text { Mliječna čokolada } \\
\text { s grožđicama, kiki- } \\
\text { rikijem, bademima } \\
\text { i lješnjacima }\end{array}$ & $\begin{array}{l}\text { Milk chocolate } \\
\text { with raisins, } \\
\text { peanuts, al- } \\
\text { monds and ha- } \\
\text { zelnuts }\end{array}$ & $\begin{array}{l}\text { Mliječna čoko- } \\
\text { lada }\end{array}$ & Milk chocolate & Chocolat au lait \\
\hline $\begin{array}{l}\text { Mliječna čokolada } \\
s \text { pšenicom } i \text { me- } \\
\text { dom }\end{array}$ & $\begin{array}{l}\text { Milk chocolate } \\
\text { with wheat and } \\
\text { honey }\end{array}$ & & & \\
\hline $\begin{array}{l}\text { Tamna čokolada } \\
\text { Bijela čokolada } \\
\text { Kakao }\end{array}$ & $\begin{array}{l}\text { Dark chocolate } \\
\text { White chocolate } \\
\text { Cocoa }\end{array}$ & & & \\
\hline
\end{tabular}

Some of these chocolate labels can be classified as partial equivalents, either because the order of information is inverted and/or some information remained untranslated (an example of the latter being Čokolada za jelo $i$ kuhanje "chocolate for eating and cooking'-Chocolate for cooking and coating), or the labels differ in

${ }^{22}$ French was attested alongside English and Croatian. 
some grammatical features (e.g. Mliječna čokolada s jagodom 'milk chocolate with strawberry'-Milk chocolate with strawberries). Some ingredients may be omitted from product description when they redundantly occur as part of product name. For example, Dorina Keks 'Dorina cookie' is described as Mliječna čokolada in Croatian because the ingredient is mentioned in the name. The English description, in turn, includes a reference to the ingredient: Milk chocolate with biscuits (Figure 9). At first glance, the label could be identified as disjoint but, technically, the same information is provided in different categories (product name vs. product description). Still, there were a few labels in the corpus that duplicate the same word in both, product name and product description (e.g. Dorina Mliječna-Mliječna čokolada, Milk chocolate).

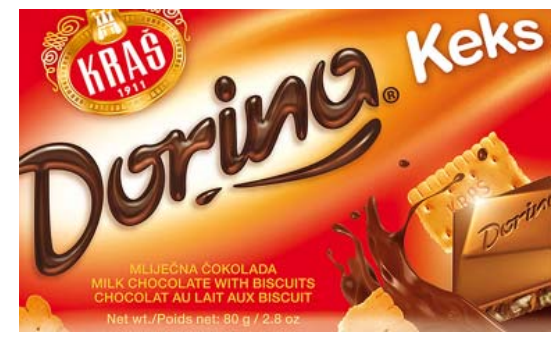

Figure 9. Omission in product description (URL 2) $)^{23}$

\subsubsection{Paralinguistic properties of chocolate labels}

Another noteworthy feature which may have a direct impact on product perception and its position in LL is the visual and graphic arrangement of the label elements. The paralinguistic properties that characterise product names in the corpus we examined include the large coloured fonts on both monolingual and bilingual labels. White, yellow, green, and brown colours on emphatic, colourful backgrounds were also found to be quite common. Their purpose is, arguably, to draw attention and make the product stand out on store shelves. Over a limited time span, a chocolate brand usually has the same graphic pattern for the name applicable to both languages. Slight distinctions are possible in terms of font size and colour in bilingual labels. If a chocolate brand plays at superior quality and importance, the use of English names is going to be even more effective if coupled with colourful design and typeface. For example, Kandit has presented a special collection of elegant and exclusive products, viz. Kandi Prestige Whole Nuts, Kandi Prestige Crunchy Nuts, and Kandi Prestige Almonds with Crunchy Caramel, all of which have English

${ }^{23}$ URL 2 http://www.kras.hr/hr/proizvodi/cokolade/dorina (last accessed on 25 June 2018). 


\section{Emilija Mustapić: \\ From šećerna tabla to čoCROlada: A study of multilingual discourse on Croatian food labels}

names emphasised with bold and italicised fonts (Figure 10). This seems consistent with Piller's (2003) observations that (a) the English text on commercial products tends to be presented with large print, colour, unusual fonts, and forms and that (b) even if the target consumer is not likely to understand the message rendered in English, the use of paralinguistic features will help activate the positive stereotypes associated with English and will most likely transfer them to the product itself. On top of that, it has been observed that a foreign language would draw longer attention than a monolingual native language text (Piller 2001), and that it becomes even more perceptible if built up by visual and graphic layout.

In sum, in the corpus of labels examined, we attested a symbiotic blend of visual and graphic devices (colour and font) and English, which conveys the image of sophistication and prestige of the products. Larger, bold fonts and stronger colours stress the product name and differentiate it from the body of the label. The latter, descriptive part, may not be as relevant for the product image as the product name. Finally, information about the ingredients and net weight, being the commercially least relevant information, is mostly given in similar fonts in both languages, lowercase black and white print, but this depends to a large extent on the background colour of the wrap (Figure 11). Partially different fonts are used sporadically to present the information about the ingredients and net weight in the two languages. The colour and font are generally consistent, with no major contrasts.

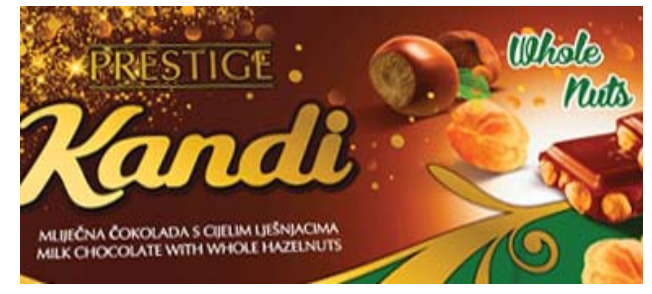

Figure 10. Colour and font presentation in product naming (URL 3$)^{24}$

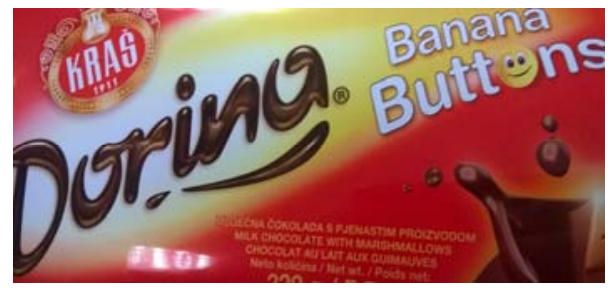

Figure 11. Visual and graphic presentation of the product description (photo taken by the author on 3 July, 2018)

\section{Conclusions}

In this paper, we have tried to position the role of chocolate, and indirectly also other food labels, and emphasise their importance in shaping the bilingual and multilingual landscape of Croatia. Unlike fixed texts, mobile or non-linear texts (prod-

${ }^{24}$ URL 3 https://www.kandit.hr/hr/proizvodi/cokolade/ (last accessed on 25 June 2018). 
uct labels among them) have not always been perceived as a part of LL, which is why their function in shaping LL has been somewhat overlooked. In recent years, however, we have witnessed a steady increase of studies focusing specifically on these kinds of texts, as outlined in Section 1 and Section 2 (e.g. Pennycook 2009; Kallen \& Ni Dhonnacha 2010; Sebba 2010; Tufi \& Blackwood 2010; Blackwood \& Tufi 2012; Peck \& Stroud 2015; Caldwell 2016, 2017). In this paper, we attempted to build on these studies by applying the theoretical paradigm of LL to the study of mobile texts printed on Croatian food labels.

Consumerism and globalisation have caused tremendous social change. Traditional, monolingual, nationally-oriented identities have changed into global, multilingual, consumerist ones. English has been a major driving force in this process; it is now perceived as an international language and has come to symbolise quality and prestige. Embracing English, with all its connotations, into a particular LL leads to the creation of a new, globally-oriented modern identity. Therefore, a sociolinguistic analysis of multilingual, i.e. English discourse on, among others, food product labels should be part of a systematic analysis of this phenomenon. Although the popularity of billboards and posters in LL research is beyond dispute, the multilingual discourse of product labels is an equally worthy object of LL study, as it helps shape a new image of the product, instils it with new (stereotypical) values, and in this way appeals to the modern consumer who is part of the shrinking, globalising world.

As we have seen in Section 5, the presence of foreign languages such as English, French, or Italian on Croatian chocolate labels can be traced back to at least the 1960s, but the majority of labels of the time were largely monolingual. The situation, however, started to change dramatically in the 1990s. The decade was marked by the beginning of multilingual advertising in chocolate labelling. From the 1990s onwards, chocolate labels have become predominantly bilingual, containing Croatian and English elements merged together in what Sebba (2012) called "overlapping" multilingualism. Bilingual chocolate labels, i.e. labels with Croatian and English words, are usually disjoint and are characterised by large, bold fonts and conspicuous colours. The product descriptions on such labels usually consist of equivalent words (i.e. words with the same meaning in two or more languages) with no specific visual or graphic instruments. They are, therefore, less affected by label design. Label names, in turn, proved more informative for our purposes, since this is where the full effect of the English influence could be observed.

While the increasing use of English on Croatian chocolate labels, especially since the 2000s could be attributed to several factors (cf. Section 5.1), we consider 


\section{Emilija Mustapić: \\ From šećerna tabla to čoCROlada: A study of multilingual discourse on Croatian food labels}

the most plausible explanation to be the companies' needs to keep up with the trends, build the image of modernity, and position themselves as important players in the global economy. The use of English linguistic elements appears to be more symbolic and intentional than informational because in many cases there are fitting Croatian alternatives that simply failed to be used. It is, therefore, not surprising to see more and more Croatian (chocolate) labels featuring monolingual, English-only names.

More studies are necessary in order to expand the existing ideas about the role of product labels in the Croatian LL. In particular, it would be worthwhile to examine labels of other product brands and types (e.g. crisps, beverages, detergents, etc.) to see if, among others, they have followed similar diachronic paths in the development of multilingual discourse. The topic also calls for a more extensive, interdisciplinary approach since product labels, and other LL signs, are affected by numerous non-linguistic factors. Finally, due to their highly complex nature and the involvement of a number of non-linguistic factors in the construction of LL, more effort must go in future to the development of sound methodologies. This includes mitigating potential limitations of particular methodological options so that the sociolinguistic realities of a particular LL can be investigated in as bias-free and objective a way as possible.

\section{References}

Babić, Stjepan. 2004. Hrvanja hrvatskoga. Školska knjiga, Zagreb.

Backhaus, Peter. 2005. Signs of multilingualism in Tokyo: a diachronic look at the linguistic landscape. International Journal of the Sociology of Language 175/176. 103-121. DOI: $10.1515 / \mathrm{ijs} 1.2005 .2005 .175-176.103$

Backhaus, Peter. 2007. Linguistic landscape. A comparative study of urban multilingualism in Tokyo. Clevedon Buffalo Toronto: Multilingual Matters LTD.

Barni, Monica \& Bagna, Carla. 2015. The critical turn in LL. New methodologies and new items in LL. Linguistic Landscape 1(1-2). 6-18. DOI: 10.1075/11.1.1-2.01bar

Ben-Rafael, Eliezer \& Shohamy, Elana \& Amara, Muhammad Hasan \& Trumper-Hecht, Nira. 2006. Linguistic landscape as symbolic construction of the public space: the case of Israel. International Journal of Multilingualism 3(1). 7-30. DOI: 10.1080/14790710608668383

Ben-Rafael, Eliezer \& Ben-Rafael, Miriam. 2015. Linguistic landscapes in an era of multiple globalizations. Linguistic Landscape 1(1-2). 19-37. DOI: 10.1075/11.1.1-2.02ben

Blackwood, Robert. 2015. LL explorations and methodological challenges. Linguistic Landscape 1(1-2). 38-53. DOI: 10.1075/11.1.1-2.03bla 


\section{EZIKOSLOVLJE \\ 20.1 (2019): 119-146}

Blackwood, Robert \& Tufi, Stefania. 2012. Policies vs. non-policies: Analysing regional languages and the national standard in the linguistic landscape of French and Italian Mediterranean cities. In Gorter, Durk \& Marten, Heiko. F. \& van Mensen, Luk (eds.), Minority languages in the linguistic landscape, 109-126. Houndsmills: Palgrave Macmillan. DOI: 10.1057/9780230360235_7

Blackwood, Robert. (forthcoming). Chestnut beer, Corsica-Cola, and wine bottles: The commodification of Corsican in the linguistic and semiotic landscapes of the island's drinks industry. International Journal of the Sociology of Language.

Bruyèl-Olmedo, Antonio \& Juan-Garau, Maria. 2009. English as a lingua franca in the linguistic landscape of the multilingual resort of S'Arenal in Mallorca. International Journal of Multilingualism 6(4). 384-411. DOI: 10.1080/14790710903125010

Busing, Frank, M. T. \& Weaver, Bruce \& Dubois, Sacha. 2016. $2 \times 2$ Tables: a note on Campbell's recommendation. Statistics in Medicine 35(8). 1354-1358. DOI: $10.1002 / \operatorname{sim} .6808$

Caldwell, David. 2016. But they didn't win the Super Bowl! Printed t-shirts as placed resources. In Nichols, Sue \& Snowden, Collette (eds), Language and literacies as mobile and placed resources, 10-29. London: Routledge.

Caldwell, David. 2017. Printed t-shirts in the linguistic landscape. A reading from functional linguistics. Linguistic Landscape 3(2). 122-148. DOI: 10.1075/11.3.2.02cal

Campbell, Ian. 2007. Chi-squared and Fisher-Irwin tests of two-by-two tables with small sample recommendations. Statistics in Medicine 26(19). 3661-3675. DOI: $10.1002 / \operatorname{sim} .2832$

Cenoz, Jasone \& Gorter, Durk. 2006. Linguistic Landscape and Minority Languages. International Journal of Multilingualism 3(1). 67-80. DOI: 10.1080/14790710608668386

Drljača, Branka. 2006. Anglizmi u ekonomskome nazivlju hrvatskoga jezika i standardnojezična norma. Fluminensia 18(1). 65-85.

Edelman, Loulou. 2006. The linguistic landscape of Kalverstraat: A pilot study. In: T. Koole, J. Nortier \& B. Tahitu (eds), Artikelen van de Vijfde sociolinguïstische conferentie, 148-155. Delft: Eburon.

Fischer, Roswitha. 2008. Studying Anglicisms. In Fischer, Roswitha \& Hanna, Pulaczewska (eds.), Anglicisms in Europe: Linguistic Diversity in a Global Context, 1-14. Cambridge Scholars Publishing.

Gjuran-Coha, Anamarija \& Pavlović, Ljiljana. 2009. Elementi reklamne retorike u hrvatskim reklamnim porukama. Fluminensia 21(1). 41-54.

Gorter, Durk. (ed.). 2006. Linguistic landscape: A new approach to multilingualism. Clevedon: Multilingualism Matters.

Gorter, Durk \& Cenoz, Jasone. 2017. Linguistic landscape and multilingualism. In: Cenoz, Jasone \& Gorter, Durk \& May Stephen (eds.), Language Awareness and Multilingualism, Encyclopedia of Language and Education, 233-245. Springer. DOI: 10.1007/978- 


\section{Emilija Mustapić: \\ From šećerna tabla to čoCROlada: A study of multilingual discourse on Croatian food labels}

\section{3-319-02240-6 27}

Griffin, Jeffrey L. 2004. The presence of written English on the streets of Rome. English Today 20(2). 3-8. DOI: 10.1017/S0266078404002020

Haarmann, Harald. 1989. Symbolic values of foreign language use-from the Japanese case to a general sociolinguistic perspective. Mouton de Gruyter. Berlin New York.

Kallen, Jeffrey, L. \& Ní Dhonnacha, Esther. 2010. Language and inter-language in urban Irish and Japanese linguistic landscapes. In Shohamy, Elana \& Ben-Rafael, Eliezer \& Barni, Monica (eds.), Linguistic landscape in the city, 19-36. Bristol: Multilingual Matters.

Katičić, Radoslav. 1992. Novi jezikoslovni ogledi. Školska knjiga, Zagreb.

Kress, Gunther. 1993. Against arbitrariness: the social production of the sing as a foundation issue in critical discourse analysis. Discourse \& Society 4(2). 169-191. DOI: 10.1177/0957926593004002003

Landry, Rodrigue \& Bourhis, Richard Y. 1997. Linguistic landscape and ethnolinguistic vitality: an empirical study. Journal of Language and Social Psychology. 23-49. DOI: 10.1177/0261927X970161002

Leeman, Jennifer \& Modan, Gabriella. 2009. Commodified language in Chinatown: a contextualized approach to linguistic landscape. Journal of Sociolinguistics. 13(3). 332362. DOI: $10.1111 / \mathrm{j} .1467-9841.2009 .00409 . x$

Malinowski, David. 2015. Opening spaces of learning in the linguistic landscape. Linguistic Landscape 1(1-2). 95-113. DOI: 10.1075/11.1.1-2.06mal

Mihaljević, Milica. 1993. Hrvatsko računalno nazivlje. Jezična analiza. Biblioteka Jezikoslovlje, knjiga 6, Hrvatska sveučilišna naklada, Zagreb.

Mihaljević, Milica. 2006. Hrvatsko i englesko računalno nazivlje. Jezik 53(2). 41-50.

Opačić, Nives. 2007. Prodor engleskih riječi u hrvatski jezik. Jezik: časopis za kulturu hrvatskoga književnoga jezika. 54(1). 22-27.

O’Laoire, Muiris \& Aronin, Larissa. 2011. Dimensions of multilingualism: material culture (paper presneted at the "7th International Conference on Third Language Acquisition and Multilingualism", Warsaw, 15-17 September 2011).

Pavlenko, Aneta \& Mullen, Alex. 2015. Why diachronicity matters in the study of linguistic landscapes. Linguistic Landscapes 1(1-2). 114-132. DOI: 10.1075/11.1.1-2.07pav

Peck, Amiena \& Stroud, Christopher. 2015. Skinscapes. Linguistic Landscape 1(1-2). 133-151. DOI: 10.1075/11.1.1-2.08pec

Pennycook, Alastair. 2009. Linguistic landscapes and the transgressive semiotics of Graffiti. In Shohamy, Elana; Gorter, Durk (eds.), Linguistic Landscape: Expanding the Scenery, 302-311. New York and London: Routledge.

Piller, Ingrid. 2001. Identity construction in multilingual advertising. Language in Society 30(2). 153-186. 


\section{EZIKOSLOVLE \\ 20.1 (2019): 119-146}

Piller, Ingrid. 2003. Advertising as a site of language contact. Annual Review of Applied Linguistics 23. 170-183. DOI: 10.1017/S0267190503000254

Reh, Mechthild. 2004. Multilingual writing: a reader-oriented typology - with examples from Lira Municipality (Uganda). International Journal of the Sociology of Language 2004(170). 1-41. DOI: 10.1515/ijsl.2004.2004.170.1.

Run, Ernest Cyril \& Chin Sien Fah. 2006. Language use in packaging: The reaction of Malay and Chinese consumers in Malaysia. Sunway Academic Journal 3. 133-145.

Sebba, Mark. 2010. Discourse in Transit. In Jaworski, Adam \& Thurlow, Chrispin (eds.), Semiotic Landscapes: Language, Image, Space, 59-76. London: Continuum.

Sebba, Mark. 2012. Multilingualism in written discourse: An approach to the analysis of multilingual texts. International Journal of Bilingualism 17(1). 97-118. DOI: $10.1177 / 1367006912438301$

Shohamy, Elana \& Waksman, Shoshi. 2009. Linguistic landscapes as an ecological arena: modalities, meanings, negotiations, education. In Shohamy, Elana \& Gorter, Durk (eds.), Linguistic Landscape: Expanding the Scenery, 313-332. New York: Routledge.

Stolac, Diana \& Vlastelić, Anastazija. 2014. Jezik reklama. Hrvatska sveučilišna naklada Filozofski fakultet Sveučilišta u Rijeci.

Stroud, Christopher \& Mpendukana, Sibonile. 2010. Multimodal signage: a multimodal approach to discourses of consumption in a South African township. Social Semiotics 20(5). 469-493, Routledge Taylor \& Francis Group. DOI: 10.1080/10350330.2010.513174

Torkington, Kate. 2009. Exploring the linguistic landscape: the case of the 'Golden Triangle' in the Algarve, Portugal. In Disney, Steve \& Forchtner, Bernhard \& Ibrahim, Wesam \& Miller, Neil (eds.), Lancaster University Postgraduate Conference in Linguistics \& Language Teaching 3: Papers from LAEL PG 2008.122-145.

Tufi, Stefania \& Blackwood, Robert. 2010. Trademarks in the linguistic landscape: Methodological and theoretical challenges in qualifying brand names in the public space. International Journal of Multilingualism 7(3). 197-210. DOI: 10.1080/14790710903568417

Underwood, L. Robert \& Ozanne, Julie L. 1998. Is your package an effective communicator? A normative framework for increasing the communicative competence of packaging. Journal of Marketing Communications 4. 207-220. DOI: $10.1080 / 135272698345762$

URL 1 http://www.chocolatewrappers.info/Vevropa/Zvecevo/zvecevo3.htm (last accessed on 1 June 2018)

URL 2 http://www.kras.hr/hr/proizvodi/cokolade/dorina (last accessed on 25 June 2018)

URL 3 https://www.kandit.hr/hr/proizvodi/cokolade/ (last accessed on 25 June 2018) 


\section{Author's address:}

University of Zadar

Obala kralja Petra Krešimira IV/2, Zadar

E-mail: emustapic@unizd.hr

\section{OD ŠEĆERNE TABLE DO ČOCROLADE: ISTRAŽIVANJE VIŠEJEZIČNOG DISKURSA NA OMOTIMA HRVATSKIH PREHRAMBENIH PROIZVODA}

Proučavanje jezičnoga krajobraza obuhvaća jezik znakova javnih ustanova, komercijalnih veleplakata i drugih oblika pisanih tekstova koji su izloženi u javnim (većinom urbanim) prostorima određenog geografskog područja. Njegova dvojna uloga, informativna i simbolička, predstavlja plodno tlo za istraživanje višejezičnosti, sveprisutnog fenomena u današnjem društvu. Jezični krajobraz sastoji se od većih entiteta kao što su veleplakati, ali i manjih, svakodnevnih poput letaka, postera i prehrambenih omota. Cilj je ovoga rada istražiti i opisati višejezični diskurs na omotima hrvatskih prehrambenih proizvoda uz poseban naglasak na pojavu riječi i izraza iz engleskog jezika. Kvantitativno istraživanje čokoladnih omota provedeno za razdoblje od 1960-ih do 2010. godine u prvom dijelu rada pokazuje kako je hrvatski jezični krajobraz usvojio engleski jezik (kao i neke druge jezike do određene mjere) te je od prvenstveno jednojezičnoga postao višejezičan. Kvalitativna analiza suvremenih omota hrvatskih čokolada u drugom dijelu rada provedena na primjeru odnosa jezičnog sadržaja te vizualnih karakteristika omotâ potvrđuje izražen utjecaj engleskog jezika na oblikovanje hrvatskog jezičnog krajobraza u području prehrambenih omota. Time se potvrđuje opće prihvaćena ideja kako je engleski jezik postao ključna sastavnica u oglašavanju proizvoda.

Ključne riječi: jezični krajobraz; omoti hrvatskih prehrambenih proizvoda; višejezičnost; engleski. 